\title{
Protocol for Ribosome Profiling in Bacteria
}

Fuad Mohammad and Allen R. Buskirk*

Department of Molecular Biology and Genetics, Johns Hopkins University School of Medicine, Baltimore, Maryland, USA

*For correspondence: buskirk@jhmi.edu

[Abstract] Ribosome profiling provides information on the position of ribosomes on mRNA on a genomic scale. Although this information is often used to detect changes in gene expression under different conditions, it also has great potential for yielding insight into the mechanism and regulation of protein synthesis itself. First developed in yeast, ribosome profiling involves the isolation and sequencing of ribosome-protected mRNA fragments generated by nuclease treatment. Since the application of ribosome profiling in bacteria has been problematic, we report here a systematically optimized protocol for $E$. coli that we have used with success for other bacteria as well. Cells are harvested by flash-freezing cultures directly in liquid nitrogen. After lysis, translation is arrested by high magnesium concentration without the use of antibiotics. These improvements eliminate artifacts induced by harvesting cells by centrifugation or filtration and by use of chloramphenicol to arrest translation. These improvements are especially appropriate for studies where the exact position of the ribosome is critical, and not merely the number of ribosomes per message, such as studies aimed at monitoring differences in local elongation rates.

Keywords: Ribosome profiling, Ribosome pausing, Translational efficiency, Gene expression, Bacteria

[Background] mRNAs are translated at varying efficiencies depending on properties inherent to the mRNA such as initiation rates, mRNA structure, and codon usage. In addition, physiological changes in the cell can alter how efficiently mRNAs are translated. Ribosome profiling was developed to monitor gene expression at the level of protein synthesis, making it possible to ask global questions about which regions of the genome are translated, when they are translated, and how translation is regulated. First developed by Ingolia and Weissman in yeast (Ingolia et al., 2009), ribosome profiling utilizes nuclease digestion to degrade regions of mRNA that are not occupied by ribosomes, generating ribosome-protected mRNA fragments that are isolated, cloned, and sequenced. When the reads are mapped back to the genome, they reveal the position of ribosomes throughout the transcriptome, providing a powerful tool to monitor translation and its regulation in vivo. Our focus here is the application of ribosome profiling to bacteria, first reported by Weissman and Bukau (Oh et al., 2011; Li et al., 2012; Becker et al., 2013). Our protocol is derived from these pioneering studies and incorporates recent improvements described by Ingolia for yeast and mammalian cells (McGlincy and Ingolia, 2017).

Ribosome profiling has been used in bacteria to identify which regions of the genome are translated, revealing novel small proteins and internal initiation sites in annotated ORFs (Shell et al., 2015; 
Meydan et al., 2019; Weaver et al., 2019). Many studies report changes in gene expression that occur upon a change in the environment, the imposition of an external stress, or the depletion of a regulatory factor (Liu et al., 2013; Subramaniam et al., 2013; Guo et al., 2014; Haft et al., 2014; Zhang et al., 2018). These studies are powerful because in exponentially growing bacteria the level of translation correlates strongly with steady-state protein levels ( $\mathrm{Li}$ et al., 2014). When supplemented with sequencing of total RNA by conventional RNA-seq, ribosome profiling data provide estimates of translational efficiency (the number of ribosomes per message). These estimates have yielded important conclusions about how the translation of proteins that form a complex occurs in the correct stoichiometry, even from a single mRNA (Li et al., 2014; Lalanne et al., 2018), and identified mRNA structure as one of the primary determinates of translational efficiency (Burkhardt et al., 2017).

In addition to these studies of gene expression, ribosome profiling can also be used to probe features of the translational machinery and the distinct phases of translation. Mechanisms of action of elongation inhibitors can be studied in vivo at codon resolution (Kannan et al., 2014; Marks et al., 2016). Factors involved in regulating translation can also be studied in detail using profiling (Balakrishnan et al., 2014; Elgamal et al., 2014; Woolstenhulme et al., 2015; Baggett et al., 2017). Another successful approach has been immunoprecipitation of factors of interest that associate with ribosomes, followed by ribosome profiling to determine where on mRNAs these factors are engaged (Oh et al., 2011). This approach has led to insights into protein folding and complex-formation during translation.

We are primarily interested in using ribosome profiling to measure local elongation rates which vary as a result of ribosome pausing at mRNA structures, rare codons, or troublesome nascent peptide sequences. Sites where ribosomes pause are expected to yield a higher number of reads than sites where elongation is fast, leading to enriched ribosome density. For these studies which rely on high resolution, it is important that the procedure to capture ribosome footprints truly reflects ribosomes in their native environment.

In our efforts to optimize the protocol for bacteria, where no standard protocol has emerged, we identified artifacts that interfere with capturing the native distribution of ribosome footprints (Mohammad et al., 2019). First, ribosome footprints in bacteria vary widely in size from as short as $15 \mathrm{nt}$ to as long as $40 \mathrm{nt}$. It is essential to capture all of these footprints to have an accurate view of translation. Second, the way that cells are harvested can alter translation and induce artifacts: addition of chloramphenicol before centrifugation induces strong pauses and leads to pile-ups of ribosomes at the 5'-end of ORFs. Harvesting by filtration also induces pauses at specific codons due to rapid depletion of aminoacyl-tRNAs. Third, translation continues after cell lysis, even in the presence of chloramphenicol. To address these problems, we developed a method of directly freezing the culture and immediately inhibiting translation with a high concentration of $\mathrm{MgCl}_{2}$. These improvements capture ribosomes as they were under growth conditions and will enable studies to more accurately detect ribosome position in vivo. For studies primarily concerned with the number of ribosomes per message (and not their exact position) we also provide the earlier filtration protocol which is simpler and useful for preparation of samples for RNA-seq. 


\section{Materials and Reagents}

1. Whatman cellulose nitrate $0.45 \mu \mathrm{m}$ filters (VWR, catalog number: 7184-009)

2. Corning ${ }^{\circledast}$ Costar $^{\circledast}$ Spin- $X^{\circledast}$ centrifuge tube filters (Sigma-Aldrich, catalog number: CLS8163-100EA)

3. Corning ${ }^{\circledR}$ Costar Cell Lifter (plastic spatula) (Sigma-Aldrich; catalog number: CLS3008)

4. 3M Overhead Sheets (PP2500)

5. Razor blades

6. Saran wrap

7. $50 \mathrm{ml}$ conical tube

8. Ti 70 polycarbonate tube

9. $18 \mathrm{G}$ needle

10. P1000 tips

11. Aluminum foil

12. CircLigase ${ }^{T M}$ ssDNA Ligase (Epicentre, catalog number: CL4115K)

13. SuperScript ${ }^{\circledR}$ III Reverse Transcriptase (Invitrogen, catalog number: 18080-044)

14. T4 RNA Ligase 2, truncated (NEB, catalog number: M0242L)

15. T4 Polynucleotide Kinase (PNK) (NEB, catalog number: M0201L)

16. Ambion SUPERase. In $^{\mathrm{TM}}$ (Invitrogen Life Technologies, catalog number: AM2696)

17. Nuclease S7 Micrococcal nuclease (MNase) (Roche, catalog number: 10107921001)

18. RNase Free DNase I (Roche, catalog number: 04716728001)

19. Phusion ${ }^{\circledR}$ High-Fidelity DNA Polymerase (NEB, catalog number: M0530L)

20. O'RangeRuler 10 bp Ladder (ThermoFisher, catalog number: SM1313)

21. Primers

a. Universal miRNA cloning linker (New England BioLabs, catalog number: S1315S)

b. Oligonucleotides from IDT:

Size control 15 mer (100 nmol) (5'-AUGUACACGGAGUCG)

Size control 45 mer (100 nmol):

(5'-AUGUACACGGAGUCGACCCGCAACGCGAUGUACACGGAGUCGACC)

c. RT primer NI-NI-9 (250 nmol, DNA oligo, 96 bases, PAGE purified Ultramer) (/5Phos/AGATCGGAAGAGCGTCGTGTAGGGAAAGAGTGTAGATCTCGGTGGTCGC/iSP 18/CACTCA/iSp18/TTCAGACGTGTGCTCTTCCGATCTATTGATGGTGCCTACAG-3)

d. PCR primer Forward (100 nmol; not gel purified):

(5'-AATGATACGGCGACCACCGAGATCTACAC)

e. PCR primer Reverse $(100$ nmol; not gel purified): (5'-CAAGCAGAAGACGGCATACGAGATNNNNNNGTGACTGGAGTTCAGACGTGTGCT CTTCCG)

Note: The underlined region of PCR primer Reverse is the sequence that corresponds to the reverse complement of the barcode. 
22. Isopropanol

23. Ethanol

24. Dry ice

25. EGTA

26. MilliQ $\mathrm{H}_{2} \mathrm{O}$

27. Sodium acetate

28. PEG 8000

29. Chloroform

30. $\mathrm{NaOH}$

31. $\mathrm{MgCl}_{2}$

32. $\mathrm{NH}_{4} \mathrm{Cl}$

33. $\mathrm{CaCl}_{2}$

34. Triton $\mathrm{X}-100$

35. NP-40

36. SDS

37. EDTA

38. DTT

39. $\mathrm{NaOAC}$

40. MOPS EZ Rich Defined Medium (Teknova, catalog number: M2105)

41. Phenol, Saturated pH 4.5 (VWR, catalog number: 97064-714)

42. Oligo Clean and Concentration kit (Zymo, catalog number: D4061)

43. Ribo-Zero ${ }^{\mathrm{TM}}$ Magnetic Kit (Gram-Negative Bacteria) (Epicentre, catalog number: MRZGN126)

44. Agilent High Sensitivity DNA Kit (Bio Analyzer) (Agilent Technologies, catalog number: 5067-4626)

45. GlycoBlue (Invitrogen Life Technologies, catalog number: AM9516)

46. SYBR ${ }^{\circledR}$ Gold Nucleic Acid Gel Stain (Invitrogen Life Technologies, catalog number: S-11494)

47. 1 M Tris, pH 8 (Life Technologies, catalog number: AM9856)

48. D-Sucrose (Fisher, catalog number: BP220-1)

49. $15 \%$ TBE Urea $1.0 \mathrm{~mm}(12+2) 45 \mu \mathrm{lgel}$ (Bio-Rad, catalog number: 345-0091) (2-3 per experiment)

50. $10 \%$ TBE Urea $1.0 \mathrm{~mm}(12+2) 45 \mu \mathrm{gel}$ (Bio-Rad, catalog number: $345-0088)(2-3 \mathrm{per}$ experiment)

51. $10 \%$ TBE Urea $1.0 \mathrm{~mm}(18+2) 30 \mu \mathrm{lgel}$ (Bio-Rad, catalog number: $345-0089)$ (1 per experiment)

52. $10 \%$ TBE Native $1.0 \mathrm{~mm}(12+2) 45 \mu \mathrm{lgel}$ (Bio-Rad, catalog number: 345-0051) (4-6 per experiment)

53. $10 x$ Lysis Buffer $(50 \mathrm{ml})$ (see Recipes)

54. Pelleting Buffer (see Recipes)

55. Resuspension Buffer (see Recipes) 
56. $10 \%$ Sucrose Gradient Buffer (see Recipes)

57. $50 \%$ Sucrose Gradient Buffer (see Recipes)

58. RNA Elution Buffer (50 ml) (see Recipes)

59. DNA Elution Buffer (50 ml) (see Recipes)

\section{Equipment}

1. Kontes $90 \mathrm{~mm}$ filtration apparatus

2. Spex Sampleprep 6870 Freezer Mill

3. Beckman Coulter Optima L-80 XP Ultracentrifuge

4. SW41 Ti rotor

5. Type 70 Ti rotor

6. Polyclear Centrifuge tubes (Seton, catalog number: 7030)

7. Polycarbonate bottle with cap for Ti 70

8. Biocomp Gradient Maker and Fractionator

9. Thermocycler

10. Eppendorf Thermomixer $R$

11. GE Typhoon Imager

12. Agilent 2100 BioAnalyzer

\section{Software}

1. Analysis of sequenced ribosome footprints was done using a custom python pipeline found in the link below: https://github.com/greenlabjhmi/2018 Bacterial Pipeline riboseq

\section{Procedure}

This protocol details every step of ribosome profiling from culturing cells up to PCR amplification of ribosome footprints in preparation for next-generation sequencing (NGS). A general outline of the workflow is described below:

\section{Day 1}

- Growth of bacterial cultures

- Harvest by whole culture freeze

- Harvest by filtration (for total RNA extraction for RNA-seq)

- Cell lysis by freezer mill

\section{Day 2}

- Pellet ribosomes over sucrose cushion 
- Nuclease digestion

- Sucrose gradient and monosome isolation

\section{Day 3}

- Phenol chloroform extraction

- Size selection gel

Day 4 (can split into 2 days)

- Gel extraction

- Dephosphorylation

- Linker ligation

- rRNA depletion

- Reverse transcription

- RT gel

\section{Day 5}

- RT gel extraction

- Circularization

- Pilot PCR

- Pilot PCR gel

- Preparative PCR

- Preparative PCR gel

\section{Day 6}

- Preparative PCR gel extraction

- Sequencing and data analyses

\section{Day 1}

A. Growth of bacterial cultures

Bacterial cultures should be grown in the appropriate medium and growth conditions. When preparing cultures, consider the volume necessary to obtain around $1 \mathrm{mg}$ of total RNA. The following conditions are used for E. coli during exponential growth:

1. Inoculate an overnight starter culture ( $25 \mathrm{ml}$ of MOPS EZ Rich media) from a single colony.

2. The next day, prepare $300 \mathrm{ml}$ of MOPS EZ Rich media and warm at $37^{\circ} \mathrm{C}$ for $1 \mathrm{~h}$ prior to inoculation.

3. Inoculate $300 \mathrm{ml}$ of MOPS media with $1 \mathrm{ml}$ of overnight culture.

4. Grow to an $\mathrm{OD}_{600}=0.3-0.5(\sim 2 \mathrm{~h})$. 
B. Harvest by whole culture freeze

This method of harvesting captures ribosomes without inducing artifacts from stress seen from harvesting by filtration or centrifugation. Under the growth conditions above, only $100 \mathrm{ml}$ of the 300 $\mathrm{ml}$ will be flash frozen. The rest can be filter harvested to collect RNA for RNA-seq or frozen as backup.

1. While cells are growing, prepare a liquid nitrogen bath:

a. Line an ice bucket with 2-3 layers of aluminum foil (see Figure 1A).

b. Fill bucket halfway with liquid nitrogen.

2. When cells are at the correct $\mathrm{OD}_{600}$, use a $50 \mathrm{ml}$ serological pipet and spray $50 \mathrm{ml}$ of the culture directly into the liquid nitrogen bath. Make sure not to spray in one area. Instead make circles in the $\mathrm{N}_{2}$ (see Figures $1 \mathrm{~B}$ and $1 \mathrm{C}$ ).

A

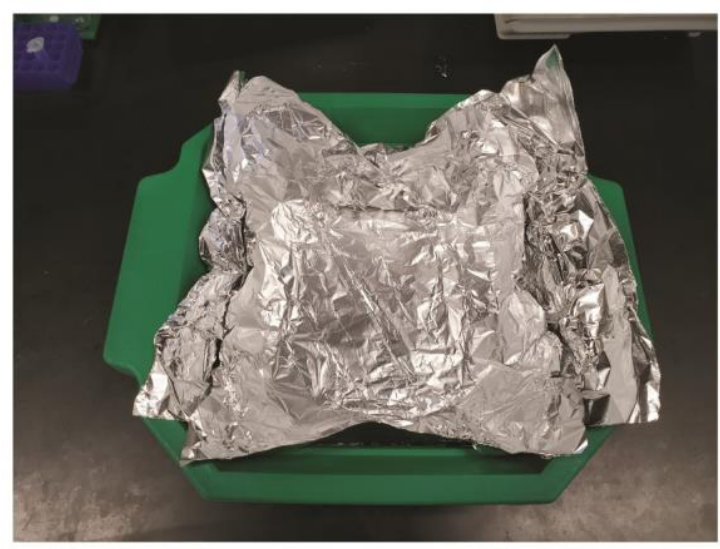

B

C
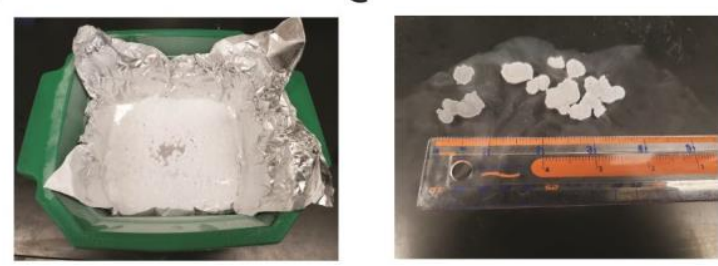

Figure 1. Liquid nitrogen bath used to freeze cultures. A. Line a standard lab ice bucket with 2-3 layers of aluminum foil. B. Add 2 inches of liquid nitrogen, then drip $100 \mathrm{ml}$ of the bacterial culture into the liquid nitrogen. C. Drips should form ice pellets about 0.25 to 0.5 inches in diameter.

3. Repeat Step B2 to collect a total of $100 \mathrm{ml}$ of culture.

4. If collecting cells for RNA-seq, immediately run the rest of the culture $(200 \mathrm{ml})$ through the filtration harvest protocol below to collect cell pellets.

5. Lift the aluminum foil and pour off the liquid nitrogen from the sample. Scrape the frozen pellets into several $50 \mathrm{ml}$ conical tubes on dry ice. Avoid thawing. 
C. Harvest by filtration (for total RNA extraction for RNA-seq)

Note: This step is needed to create a sample matched RNA-seq library and can be skipped if RNA-seq is not necessary.

1. Set up the Kontes $90 \mathrm{~mm}$ filtration apparatus with Whatman cellulose nitrate $0.45 \mu \mathrm{m}$ filters during cell growth.

2. Pour $\sim 200 \mathrm{ml}$ of culture into the Kontes $90 \mathrm{~mm}$ filtration apparatus and turn on the vacuum.

3. While the media is filtering, gently but quickly scrape with a plastic spatula along the surface until you get a good clump of cells. Freeze in liquid nitrogen.

Note: You should be able to do this twice in about $60 \mathrm{~s}$. The sample should never go dry-the dryness and cold that comes with losing all the media stresses the cells.

4. Place pellets in a $50 \mathrm{ml}$ conical tube and store at $-80^{\circ} \mathrm{C}$, do not allow any thawing.

5. RNA can be extracted using RNA extraction kits or phenol extraction from the cell pellet.

6. Extracted RNA can then be used to crate RNA-seq using commercially available kits.

D. Cell lysis by freezer mill

Lysis is done through mechanical grinding of the frozen culture. The lysis buffer used contains 150 $\mathrm{mM} \mathrm{MgCl} 2$ to inhibit translation in the lysate.

1. Pre-Chill Mixer Mill grinding cylinders and $3 \times 50 \mathrm{ml}$ conical tubes on dry ice.

2. Measure $50 \mathrm{~g}$ of frozen culture, making sure to avoid thawing. Add $5.5 \mathrm{ml}$ of $10 \mathrm{x}$ lysis buffer to large grinding cylinder and allow it to freeze.

3. Transfer $50 \mathrm{~g}$ frozen culture into the grinding cylinder.

4. Grind using the following cycles: 10 cycles, $10 \mathrm{~Hz}, 5$ min precool, 1 min run, 1 min cool. Note: The grinding protocol used here was optimized to maximize RNA yield while maintaining polysome integrity visualized by sucrose gradient sedimentation. We recommend revalidating grinding settings if using a different model Mixer Mill or a different organism.

5. Transfer the pulverized cells into the pre-chilled $50 \mathrm{ml}$ conical tubes.

6. Store at $-80^{\circ} \mathrm{C}$ for later use, or continue.

\section{Day 2}

E. Pelleting ribosomes over sucrose cushion

1. Thaw lysate on benchtop until thawed (1-2 h, mixing every $10 \mathrm{~min})$. Place on ice immediately after thawed.

2. Pre-clear lysate by spinning for 10 min at $9,000 \times g$ at $4{ }^{\circ} \mathrm{C}$ to remove cellular debris.

3. Prepare two sucrose cushions per sample:

a. Transfer $3 \mathrm{ml}$ of pre-chilled pelleting buffer into a Ti 70 polycarbonate tube $\times 2$.

b. Layer $22 \mathrm{ml}$ lysate gently on top of cushion $\times 2$.

c. Spin at $370,000 \times g(60,000 \mathrm{rpm})$ for $1.5 \mathrm{~h}$ at $4^{\circ} \mathrm{C}$ in a Ti 70 rotor to pellet ribosomes.

4. Remove supernatant from the ribosome pellet and rinse each pellet with $150 \mu \mathrm{l}$ of pre-chilled Resuspension Buffer without disturbing pellet. 
5. To resuspended pellet:

a. Add $100 \mu$ l of Resuspension Buffer to each pellet.

b. Gently vortex for $5 \mathrm{~min}$, making sure the ribosome pellet is fully dissolved.

c. Combine the 2 tubes for a total of $200 \mu$ resuspended pellet.

6. Measure $\mathrm{A}_{260}$ of a 1:100 dilution using water.

7. Calculate the amount needed for $12.5 \mathrm{AU}$ (roughly $0.5 \mathrm{mg} \mathrm{RNA}$ ), where $\mathrm{AU}=1 \mathrm{ml}$ solution with a given $\mathrm{A}_{260}$.

Note: If sample is less than $12.5 \mathrm{AU}$, lyse and pellet the other $50 \mathrm{ml}$ of frozen culture. Resuspend with the first $200 \mu \mathrm{l}$ collected. As little as $5 \mathrm{AU}$ can be used for library preparation, but this is not recommended.

a. $12.5 \mathrm{AU} /\left(\mathrm{A}_{260}\right.$ * $\left.100 / 1,000\right)=\mu \mathrm{l}$ needed (this takes into account the 100 -fold dilution)

b. Use the calculation above to calculate the volume needed for $12.5 \mathrm{AU}$, and add Resuspension Buffer to bring volume to $200 \mu \mathrm{l}$.

8. Freeze at $-80^{\circ} \mathrm{C}$ to store or continue.

F. Nuclease digestion

Use 12.5 AU of sample in $200 \mu$ that was pelleted for nuclease digestion.

Note: If sample is less than $12.5 \mathrm{AU}$, scale the MNase accordingly.

1. Add $6 \mu$ of SUPERase-In.

2. Add $2 \mu \mathrm{l}$ of $375 \mathrm{U} / \mu \mathrm{l}$ MNase (total of $750 \mathrm{U}$ ).

3. Incubate at $25^{\circ} \mathrm{C}$ for $1 \mathrm{~h}$ shaking at $1,400 \mathrm{rpm}$ (thermomixer).

4. Add $2 \mu \mathrm{l}$ of $0.5 \mathrm{M}$ EGTA pH 8 to quench the reaction (EGTA chelates calcium to quench MNase, a calcium dependent enzyme).

5. Return to ice until next step.

G. Sucrose gradient and monosome isolation

1. Fill SW41 Polyallomer tubes with $6 \mathrm{ml}$ of $50 \%$ Sucrose Gradient Buffer and layer on top $\sim 6 \mathrm{ml}$ of $10 \%$ Sucrose Gradient Buffer (all the way to the top of the tube).

2. Put on rubber caps carefully to allow any air bubbles to escape through the hole in the cap.

3. Rotate the tubes on the Biocomp gradient maker using the following settings:

Time $=1: 48 \mathrm{~s}$

Angle $=81.5^{\circ}$

Speed $=17 \mathrm{rpm}$

4. Remove rubber caps and $150 \mu \mathrm{l}$ off the top of the gradient to make room for the sample.

5. Gently layer $200 \mu \mathrm{l}$ of the sample on top of gradient and balance in rotor tubes (sample should be approximately $210 \mu \mathrm{l}$ ).

6. Spin in ultracentrifuge at $201,000 \times g(35,000 \mathrm{rpm})$ for $2.5 \mathrm{~h}$ at $4{ }^{\circ} \mathrm{C}$ using acceleration and deceleration setting of 7 .

7. Prepare sucrose gradient fraction collector following the manufacturer's instructions. 
8. Set fraction collection so that each fraction has approximately $350 \mu \mathrm{l}$.

9. Fractionate the sucrose gradient. Keep $\sim 3$ monosome fractions $(\sim 1,050 \mu \mathrm{l})$ (Figure 2A).

10. Freeze fractions in liquid nitrogen and store at $-80^{\circ} \mathrm{C}$.

\section{Day 3}

H. Phenol chloroform extraction

Note: Use screwcap tubes and pipette in the fume hood. Spin steps are done on a tabletop centrifuge at $>10,000 \times g$ at room temperature (RT) unless otherwise specified.

1. Pre-warm $750 \mu \mathrm{l}$ of phenol, saturated $\mathrm{pH} 4.5$ at $65^{\circ} \mathrm{C}$ in thermomixer.

2. Add $57.1 \mu \mathrm{l}$ of $20 \%$ SDS to $1 \mathrm{ml}$ of sample.

3. Add sample to heated phenol.

4. Incubate and shake for $5 \mathrm{~min}$ at $65^{\circ} \mathrm{C}$ at $1,400 \mathrm{rpm}$ on the thermomixer. Occasionally pull the tubes during this period and vortex on a full speed bench vortexer.

5. Chill samples on ice for $5 \mathrm{~min}$.

6. Spin for 2 min.

7. Keep the bottom aqueous layer and add to a tube containing $700 \mu \mathrm{l}$ of phenol, saturated $\mathrm{pH}$ 4.5 at room temperature.

Important: Due to the high concentration of sucrose, there is layer inversion and the aqueous layer is on the bottom.

8. Vortex for $5 \mathrm{~min}$ at room temperature.

9. Spin for $2 \mathrm{~min}$.

10. Keep the bottom aqueous layer and add to $600 \mu$ l of chloroform.

11. Vortex for $30 \mathrm{~s}$.

Note: If the samples become cloudy, warm to $\sim 30^{\circ} \mathrm{C}$. This is likely the SDS falling out of solution.

12. Spin for $2 \mathrm{~min}$.

13. Keep the top aqueous layer $(\sim 1 \mathrm{ml})$ and place in a $15 \mathrm{ml}$ conical tube.

14. Add 1 volume $(1 \mathrm{ml})$ of $\mathrm{MilliQ} \mathrm{H}_{2} \mathrm{O}$ to dilute the sucrose.

15. Add $3 \mathrm{M}$ of sodium acetate ( $\mathrm{pH} 5.5)$ to a final concentration of $0.3 \mathrm{M}(\sim 200 \mu \mathrm{l})$.

16. Add an equal volume of isopropanol and mix well.

17. Precipitate the RNA ( 30 min on dry ice, or overnight $-20^{\circ} \mathrm{C}$ ).

18. Centrifuge in Eppendorf $5804 \mathrm{R}$ at $12,000 \times \mathrm{g}(\sim 9,000 \mathrm{rpm})$ for $30 \mathrm{~min}$. Set temperature to $4{ }^{\circ} \mathrm{C}$.

19. Remove as much liquid as possible without disturbing the pellets.

20. Air dry samples in the hood.

21. Resuspend in $40 \mu \mathrm{l}$ of MilliQ $\mathrm{H}_{2} \mathrm{O}$ or $10 \mathrm{mM}$ Tris $\mathrm{pH} 8$ and transfer to a $1.7 \mathrm{ml}$ tube.

22. Measure $A_{260}$.

23. You will run approximately $20 \mu \mathrm{g}$ on the size selection gel.

24. Store samples at $-80^{\circ} \mathrm{C}$. 
I. Size selection gel

1. Prepare samples:

$20 \mu \mathrm{g}$ Sample RNA + 2x RNA Loading Dye (NEB)

Ladder (oligos: $15 \mathrm{nt}$ and $45 \mathrm{nt})=\mathrm{Mix} 3 \mu \mathrm{l}(10 \mu \mathrm{M}$ stock) of each marker size $+6 \mu \mathrm{l} 2 \mathrm{x}$ RNA Loading Dye per lane. Load $6 \mu$ in one lane (enough for 2 gels)

2. Heat samples and ladder at $80^{\circ} \mathrm{C}$ for $2 \mathrm{~min}$, then place on ice.

3. Prepare $15 \%$ TBE Urea $1.0 \mathrm{~mm}(12+2) 45 \mu \mathrm{lgel}$.

4. Load samples carefully with at least one empty lane between samples.

5. Run gel(s) until bromophenol blue is $3 / 4$ down the gel.

If running at $15 \mathrm{~W}$ :

$1 \mathrm{gel}=17 \mathrm{~min}$

2 gels $=30 \mathrm{~min}$

6. Remove gels from plates and place in SYBR-gold stain $(100 \mathrm{ml}$ of $1 \mathrm{x}$ TBE $+10 \mu \mathrm{l}$ of SYBR-gold) for $5 \mathrm{~min}$.

7. Remove from stain and place on transparency film, then cover with saran wrap.

8. Scan on the GE Typhoon Imager using the fluorescence setting for SYBR Gold. Use a 350-400 PMT.

9. Print the gel as actual size and use printout as a cutting guide to cut sections out of the gel. Cut from the top of the upper marker ( $45 \mathrm{nt}$ ) to bottom of lower marker (15 nt) (Figure 2B).

10. Cut out $15 \mathrm{nt}$ and $45 \mathrm{nt}$ markers and treat as a control sample. This can be used to assess proper ligation and reverse transcription later on.

11. Rescan gel to confirm proper cutting.

12. For elution, crush gel by doing the following:
a. Place gel cutout into a $0.5 \mathrm{ml}$ tube with holes poked through the bottom (18 $\mathrm{G}$ needle).
b. Place the $0.5 \mathrm{ml}$ tube in a $1.7 \mathrm{ml}$ tube to collect the gel.
c. Spin for $5 \mathrm{~min}$, gel should extrude from the $0.5 \mathrm{ml}$ tube into the bottom $1.7 \mathrm{ml}$ tube.
d. Make sure to collect any remaining gel from the $0.5 \mathrm{ml}$ tube.

Day 4 (can be split into 2 days)

J. Gel extraction

1. Add $500 \mu \mathrm{l}$ of RNA Elution Buffer to each sample.

2. Add $2.5 \mu$ of SUPERase-Inhibitor to each sample.

3. Shake overnight in a thermomixer, $1,400 \mathrm{rpm}$ at $4{ }^{\circ} \mathrm{C}$.

4. The next day, briefly spin samples.

5. Transfer gel slurry into Spin-X columns (using P1000 tips with the ends cut off).

6. Spin for $3 \mathrm{~min}$ at $20,000 \times g$ at room temperature.

7. Put eluate into a new $1.7 \mathrm{ml}$ tube.

8. Add $2 \mu$ of GlycolBlue to each sample.

9. Add $650 \mu \mathrm{l}$ of isopropanol. 
10. Precipitate (40 min-dry ice), spin for $30 \mathrm{~min}$ at $>10,000 \times \mathrm{g}, 4^{\circ} \mathrm{C}$.

11. Remove supernatant, and gently wash with $\sim 100 \mu$ of $80 \%$ cold ethanol.

12. Dry pellets by speed vac (10 min).

13. Resuspend pellet in $5 \mu$ of MilliQ $\mathrm{H}_{2} \mathrm{O}$.

K. Dephosphorylation

Reaction Mix (per sample)

$1 \mu \mathrm{l}$ of $10 \mathrm{x}$ PNK buffer

$1 \mu \mathrm{l}$ of SUPERase-In

$2 \mu \mathrm{l}$ of MilliQ $\mathrm{H}_{2} \mathrm{O}$

1. Heat samples collected from $\mathrm{J} 13$ at $80^{\circ} \mathrm{C}$ for $2 \mathrm{~min}$ and then place on ice.

2. Add $4 \mu \mathrm{l}$ of Reaction Mix to each sample.

3. Add $1 \mu \mathrm{l}$ of PNK to each sample $(10 \mathrm{~K} \mathrm{U} / \mu \mathrm{l})$.

4. Incubate at $37^{\circ} \mathrm{C}$ for $1 \mathrm{~h}$.

L. Linker ligation

Reaction Mix (per sample):

$1 \mu \mathrm{l}$ of $10 \mathrm{x}$ Ligation Buffer

$0.4 \mu \mathrm{l}$ of $50 \mu \mathrm{M}$ Universal miRNA cloning linker

$7.6 \mu \mathrm{l}$ of $50 \%$ PEG 8000

Note: Ligation buffer and PNK buffer are nearly identical, so half of the required ligation buffer is used.

1. Add $9 \mu \mathrm{l}$ of Reaction Mix to each sample. Any white precipitate is assumed to be glycogen coming out as a result of the PEG.

2. Add $1 \mu \mathrm{l}$ of T4 RNA ligase 2 truncated to each sample.

3. Incubate at $37^{\circ} \mathrm{C}$ for $3 \mathrm{~h}$.

4. Clean up with oligo and concentration kit and elute in $15 \mu \mathrm{l}$ of MilliQ $\mathrm{H}_{2} \mathrm{O}$.

M. rRNA depletion

Deplete rRNA for all samples except the $15 \mathrm{nt}$ and $45 \mathrm{nt}$ controls.

1. Follow Ribo-Zero kit instructions for rRNA depletion.

2. Clean up with oligo and concentration kit and elute in $15 \mu \mathrm{l}$ of MilliQ $\mathrm{H}_{2} \mathrm{O}$.

N. Reverse transcription (RT)

Reaction Mix (per sample):

$4 \mu \mathrm{l}$ of $5 x$ RT buffer

$1 \mu \mathrm{l}$ of $10 \mathrm{mM}$ dNTPs 
$1 \mu \mathrm{l}$ of $0.1 \mathrm{M}$ DTT

$1 \mu \mathrm{l}$ of SUPERase-In

1. Use $10.75 \mu \mathrm{l}$ of sample for RT, save the other $4.25 \mu \mathrm{l}$.

2. Add $1.25 \mu \mathrm{l}$ of RT primer NI-NI-9 (10 $\mu \mathrm{M}$ stock) and heat sample to $80^{\circ} \mathrm{C}$ for $2 \mathrm{~min}$, then chill on ice.

3. Add $7 \mu$ of Reaction mix to each sample.

4. Add $1 \mu$ l of Superscript III RT to each sample (Invitrogen 56575).

5. Incubate at $48^{\circ} \mathrm{C}$ for $30 \mathrm{~min}$.

6. Add $2.2 \mu \mathrm{l}$ of $1 \mathrm{M} \mathrm{NaOH}$ to each sample.

7. Heat to $98^{\circ} \mathrm{C}$ for $20 \mathrm{~min}$.

8. Add $28 \mu \mathrm{l}$ of MilliQ $\mathrm{H}_{2} \mathrm{O}$.

9. Clean up with oligo and concentration kit (Zymo) and elute in $10 \mu$ of $\mathrm{MilliQ}_{2} \mathrm{H}_{2} \mathrm{O}$.

O. RT Gel

1. Prepare Samples:

$10 \mu \mathrm{l}$ of sample cDNA $+10 \mu \mathrm{l}$ of $2 x$ RNA Loading Dye

$5 \mu \mathrm{l}$ of $10 \mathrm{bp}$ O'RangeRuler ladder

Note: The sample containing the 15 and 45 nt markers will be used to indicate proper ligation and reverse transcription, and act as size markers for gel excision.

2. Heat to $80^{\circ} \mathrm{C}$ for 2 min and then put on ice.

3. Prepare $10 \%$ TBE Urea $1.0 \mathrm{~mm}(18+2) 30 \mu \mathrm{lgel}$.

4. Load samples carefully with at least one empty lane between samples.

5. Run gel(s) until xylene cyanol is run off the gel.

If running at $15 \mathrm{~W}$ :

$1 \mathrm{gel}=40 \mathrm{~min}$

2 gels $=60 \mathrm{~min}$

6. Remove gels from plates and place in SYBR-gold stain ( $100 \mathrm{ml} \mathrm{1x} \mathrm{TBE}+10 \mu \mathrm{l} \mathrm{SYBR-gold})$ for 5 min.

7. Remove from stain and place on transparency film, then cover with saran wrap.

8. Scan on the GE Typhoon Imager using the fluorescence setting for SYBR Gold. Use a 350-400 PMT.

9. Print the gel as actual size and use printout as a cutting guide to cut sections out of the gel. Cut from the top of the upper marker ( $45 \mathrm{nt}$ ) to bottom of lower marker (15 nt) (Figure 2C).

Important: Avoid excess RT primer band (band below 15 nt marker, 110 nt in size determined by the O'RangeRuler ladder).

10. Rescan to confirm proper cutting.

11. For elution, crush gel by doing the following:

a. Place gel cutout into a $0.5 \mathrm{ml}$ tube with holes poked through the bottom (18 $\mathrm{G}$ needle). 
b. Place the $0.5 \mathrm{ml}$ tube in a $1.7 \mathrm{ml}$ tube to collect the gel.

c. Spin for $4 \mathrm{~min}$, gel should extrude from the $0.5 \mathrm{ml}$ tube into the bottom $1.7 \mathrm{ml}$ tube.

\section{Day 5}

P. RT Gel Extraction

1. Add $500 \mu$ DNA Elution Buffer to each sample.

2. Shake overnight in thermomixer $1,050 \mathrm{rpm}$ at $25^{\circ} \mathrm{C}$ (room temperature).

3. The next day, briefly spin samples.

4. Transfer gel slurry into Spin-X columns (using P1000 tips with the ends cut off).

5. Spin for $3 \mathrm{~min}$.

6. Put eluate in new $1.7 \mathrm{ml}$ tube.

7. Add $2 \mu \mathrm{l}$ of GlycoBlue to each sample.

8. Add $650 \mu \mathrm{l}$ of isopropanol.

9. Precipitate (40 min-dry ice), spin for $30 \mathrm{~min}$ at $>10,000 \times \mathrm{g}, 4^{\circ} \mathrm{C}$.

10. Remove supernatant, and gently wash with $\sim 100 \mu \mathrm{l} 80 \%$ cold ethanol.

11. Dry pellets by speed vac ( $10 \mathrm{~min})$.

12. Resuspend pellets in $15 \mu \mathrm{l}$ of $10 \mathrm{mM}$ Tris $\mathrm{pH} 8$.

Q. Circularization

Reaction mix (per sample):

$2 \mu \mathrm{l}$ of CircLigase ${ }^{\mathrm{TM}}$ buffer

$1 \mu \mathrm{l}$ of $1 \mathrm{mM}$ ATP (from CircLigase ${ }^{\mathrm{TM}} \mathrm{Kit}$ )

$1 \mu \mathrm{l}$ of $50 \mathrm{mM} \mathrm{MnCl}_{2}$ (from CircLigase ${ }^{\mathrm{TM}} \mathrm{Kit}$ )

1. Add $4 \mu$ of Reaction Mix to each sample

2. Add $1 \mu \mathrm{l}$ of Circ ligase to each sample.

3. Incubate at $60^{\circ} \mathrm{C}$ for $60 \mathrm{~min}$.

4. Incubate at $80^{\circ} \mathrm{C}$ for $10 \mathrm{~min}$, then put on ice.

R. Pilot PCR

The goal of the PCR step is to amplify the sample while minimizing PCR amplification bias and over-amplification. To estimate the cycles of PCR needed for proper amplification, several pilot cycles are run to visualize the point at which over-amplification occurs.

\section{Reaction Mix (6 samples)}

$40 \mu \mathrm{l}$ of HF Buffer (F-518)

$4 \mu \mathrm{l}$ of $10 \mathrm{mM}$ dNTPs

$1 \mu \mathrm{l}$ of $100 \mu \mathrm{M}$ PCR primer Forward

$2 \mu \mathrm{l}$ of Phusion polymerase (F-530) 
$133 \mu \mathrm{l}$ of MilliQ $\mathrm{H}_{2} \mathrm{O}$

1. Prepare Reaction mix.

2. Combine in a $1.7 \mathrm{ml}$ tube:

$27 \mu$ l Reaction mix

$1.5 \mu \mathrm{l}$ barcoded PCR primer Reverse $(10 \mu \mathrm{M})$

$1.5 \mu$ Sample

3. Divide this into $3 \times 9 \mu \mathrm{l}$ aliquots into $0.5 \mathrm{ml}$ tubes.

4. Run on PCR protocol:

Step 1: $98^{\circ} \mathrm{C}-30 \mathrm{~s}$

Step 2: $98^{\circ} \mathrm{C}-10 \mathrm{~s}$

Step 3: $65^{\circ} \mathrm{C}-10 \mathrm{~s}$

Step 4: $72{ }^{\circ} \mathrm{C}-5 \mathrm{~s}$

Step 5: go to step 2-8 times

Step 6: $4^{\circ} \mathrm{C}$-forever

End

Each sample will have 3 aliquots in the PCR machine. Take one aliquot from each sample out of the PCR machine at the end of 5, 7, and 9 PCR amplification cycles.

Notes:

a. Pause the machine at $72{ }^{\circ} \mathrm{C}$, wait for $5 \mathrm{~s}$.

b. Quickly remove tubes and place directly on ice.

c. Quickly close the lid and continue the program.

5. Each sample will now have 3 PCR products made from 3 different PCR cycle numbers.

6. Proceed to Pilot PCR gel.

S. Pilot PCR gel

1. Prepare Samples:

$9 \mu \mathrm{l}$ of PCR sample $+2 \mu \mathrm{l}$ of $6 \mathrm{x}$ DNA Loading Dye

$5 \mu \mathrm{l}$ of $10 \mathrm{bp}$ O'RangeRuler ladder

2. Prepare $10 \%$ TBE Native $\mathbf{1 . 0} \mathrm{mm}(\mathbf{1 2}+2) \mathbf{4 5} \mu \mathrm{l} \mathrm{gel}$.

3. Load samples carefully, grouping each sample together with the cycle numbers in ascending order.

4. Run gel(s) until xylene cyanol is run off the gel.

If running at $15 \mathrm{~W}: \mathrm{z}$.

$1 \mathrm{gel}=40 \mathrm{~min}$

2 gels $=60 \mathrm{~min}$

5. Remove gels from plates and place in SYBR-gold stain $(100 \mathrm{ml}$ of $1 \mathrm{x}$ TBE $+10 \mu \mathrm{l}$ of SYBR-gold) for $5 \mathrm{~min}$.

6. Remove from stain and place on transparency film, then cover with saran wrap. 
7. Scan on the GE typhoon Imager using the fluorescence setting for SYBR Gold. Use a 350-400 PMT (Figure 2D).

8. Determine how many cycles are needed to obtain a good band around 150-190 bp without any larger molecular weight products.

Note: The ideal number of cycles gives you a nice product band but no trace of higher molecular weight products. Be very careful to avoid this because when you see higher molecular weight products, bias is likely being introduced. After determining the appropriate number of cycles from the Pilot PCR, run the Preparative $P C R$ at 1 fewer cycles to ensure that no high weight bands (usually a smear) emerge.

9. Proceed to Preparative PCR.

T. Preparative PCR

Determine the proper cycle count for each sample. Follow the same steps as the pilot PCR, but do not divide the reaction.

1. Combine in $1.7 \mathrm{ml}$ tube:

$27 \mu \mathrm{l}$ of Reaction mix

$1.5 \mu \mathrm{l}$ of barcoded PCR primer $(10 \mu \mathrm{M})$ (can use either Ni or IDX primers)

$1.5 \mu \mathrm{l}$ of Sample

2. Run PCR using the cycle count determined from the pilot PCR.

U. Preparative PCR gel

1. Prepare Samples:

$30 \mu \mathrm{l}$ of PCR sample $+6 \mu \mathrm{l}$ of $6 \mathrm{x}$ DNA Loading Dye

$5 \mu$ of 10 bp O'RangeRuler ladder

2. Prepare $10 \%$ TBE Native $1.0 \mathrm{~mm}(12+2) 45 \mu \mathrm{gel}$.

3. Load samples carefully, leaving one lane empty between samples.

4. Run gel(s) until xylene cyanol is run off the gel.

If running at $15 \mathrm{~W}$ :

$1 \mathrm{gel}=40 \mathrm{~min}$

2 gels $=60 \mathrm{~min}$

5. Remove gels from plates and place in SYBR-gold stain $(100 \mathrm{ml}$ of $1 \mathrm{x}$ TBE $+10 \mu \mathrm{l}$ of SYBR-gold) for $5 \mathrm{~min}$.

6. Remove from stain and place on transparency film, then cover with saran wrap.

7. Scan on the GE Typhoon Imager using the fluorescence setting for SYBR Gold. Use a 350-400 PMT.

8. Print the gel as actual size and use printout as a cutting guide to cut sections out of the gel. Cut from the 150 bp marker to the 200 bp marker (Figure 2E).

Important: Avoid the excess RT primer band (runs at 140 bp mark).

9. Rescan to confirm proper cutting. 
10. For elution, crush gel by doing the following:
a. Place gel cutout into a $0.5 \mathrm{ml}$ tube with holes poked through the bottom ( $18 \mathrm{G}$ needle).
b. Place the $0.5 \mathrm{ml}$ tube in a $1.7 \mathrm{ml}$ tube to collect the gel.
c. Spin for $5 \mathrm{~min}$, gel should extrude from the $0.5 \mathrm{ml}$ tube into the bottom $1.7 \mathrm{ml}$ tube.

\section{Day 6}

V. Preparative PCR gel extraction

1. Add $500 \mu \mathrm{l}$ of DNA Elution Buffer to each sample.

2. Shake overnight in thermomixer-1,050 rpm at $25^{\circ} \mathrm{C}$ (room temperature).

3. The next day, briefly spin samples.

4. Transfer gel slurry into Spin-X columns (using P1000 tips with the ends cut off).

5. Spin for 3 min at $20,000 \times g$ at RT.

6. Put eluate in new $1.7 \mathrm{ml}$ tube.

7. Add $2 \mu$ of GlycoBlue to each sample.

8. Add $650 \mu \mathrm{l}$ of isopropanol.

9. Precipitate (40 min-dry ice), spin for $30 \mathrm{~min}$ at $>10,000 \times \mathrm{g}, 4^{\circ} \mathrm{C}$.

10. Remove supernatant, and gently wash with $\sim 100 \mu \mathrm{l}$ of $80 \%$ cold ethanol.

11. Dry pellets by speed vac (10 $\mathrm{min})$.

12. Resuspend pellets in $10 \mu$ of $10 \mathrm{mM}$ Tris $\mathrm{pH} 8$.

13. Check size and concentration using a BioAnalyzer.

W. Sequencing and data analyses

1. Dilute an aliquot of each library to $2 \mathrm{nM}$ and combine together to multiplex.

2. Submit $10 \mu \mathrm{l}$ of $2 \mathrm{nM}$ multiplexed sample for 50 cycles, single-end sequencing on the lllumina HiSeq 2500.

3. Process the sequencing data with custom python 2.7 scripts available here: https://github.com/greenlabjhmi/2018 Bacterial Pipeline riboseq.

4. In broad strokes, the Jupyter notebook Github-Ribo_Density.ipynb.

a. Remove the linker CTGTAGGCACCATCAATAGATCGGAAGAGCACACGTCTGAACTCCA GTCA from the 3'-end of reads using Skewer version 0.2.2.

b. Use Bowtie version 0.12.7 to align reads to indices including ladder oligos, tRNA, and rRNA; reads that do not map to these indices are then mapped to the E. coli genome (NC_000913.2) allowing two mismatches and requiring unique mapping to a single site.

c. Write out ribosome density as a WIG file, as a binary file, and a size-separated dictionary using the 3 '-end of reads to assign ribosome position.

5. The Jupyter notebook Github-Ribo-Analysis.ipynb provides further analyses including plots of average ribosome density at start or stop codons, the calculation of pause scores at specific codons, reading frame, and the degree of drop-off across genes (their asymmetry scores). 
A

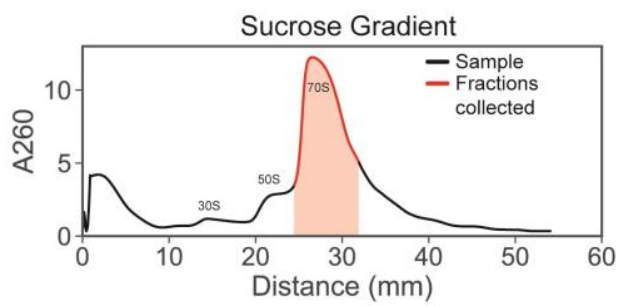

C

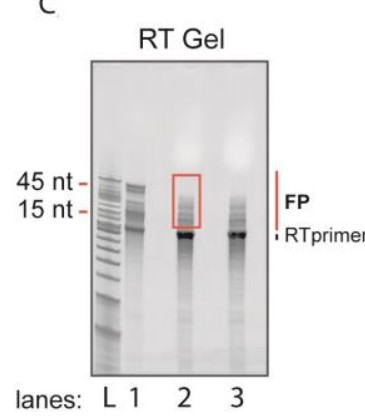

D

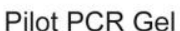

B Size Selection Gel

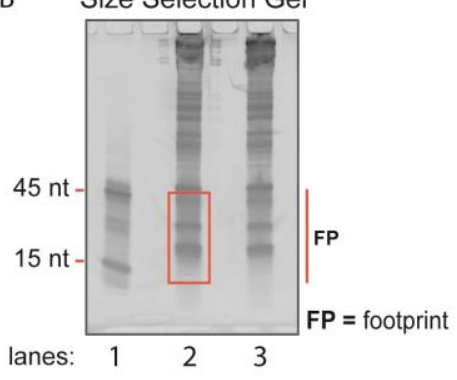

E

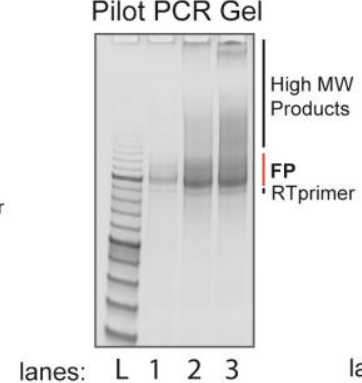

Preparative PCR Gel

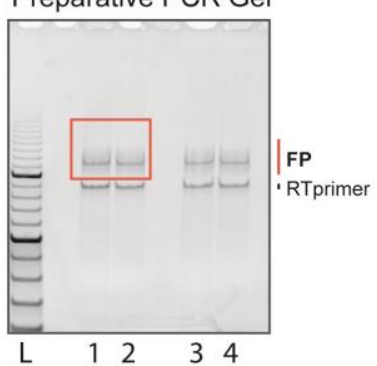

Figure 2. Ribosome profiling sucrose gradients and gels. A. Sucrose gradient trace from Step G9. A volume of $\sim 1,050 \mu \mathrm{l}$ was collected (highlighted in red) containing 70 S ribosomes. B. Size selection gel from Step 19. Lane 1: $15 \mathrm{nt}$ and $45 \mathrm{nt}$ size markers. Lanes 2 and 3: RNA from fractionated monosomes. The red box indicates the excised region containing ribosome footprints (FP). C. Reverse transcription gel from Step O9. Lane 1: ligated and reverse transcribed $15 \mathrm{nt}$ and $45 \mathrm{nt}$ size markers. Lanes 2 and 3: ligated and reverse transcribed ribosome footprints. The red box indicates excised region which avoids the excess RT primer band. D. Pilot PCR gel from Step S7. Lanes 1-3: PCR amplified products after 5, 7, and 9 PCR cycles. Note the appearance of unwanted high molecular weight products after 7 and 9 PCR cycles. E. Preparative PCR gel from Step U8. The red box indicates excised region which avoids the RT primer band. FP = ribosome footprints. $L=$ O'RangeRuler 10 bp ladder.

\section{$\underline{\text { Recipes }}$}

Note: All concentrations listed are final concentrations.

1. 10x Lysis Buffer (50 ml)

$200 \mathrm{mM}$ Tris $\mathrm{pH} 8$

$1.5 \mathrm{M} \mathrm{MgCl}_{2}$

$1 \mathrm{M} \mathrm{NH}_{4} \mathrm{Cl}$

$50 \mathrm{mM} \mathrm{CaCl}_{2}$

$4 \%$ Triton X-100

$1 \%$ NP-40

MilliQ $\mathrm{H}_{2} \mathrm{O}$

2. Pelleting Buffer 

1.1 M Sucrose
$20 \mathrm{mM}$ Tris $\mathrm{pH} 8$
$500 \mathrm{mM} \mathrm{NH}_{4} \mathrm{Cl}$
$10 \mathrm{mM} \mathrm{MgCl} 2$
$0.5 \mathrm{mM}$ EDTA pH 8
MilliQ $\mathrm{H}_{2} \mathrm{O}$

3. Resuspension Buffer

$20 \mathrm{mM}$ Tris $\mathrm{pH} 8$

$15 \mathrm{mM} \mathrm{MgCl}_{2}$

$100 \mathrm{mM} \mathrm{NH}_{4} \mathrm{Cl}$

$5 \mathrm{mM} \mathrm{CaCl}_{2}$

MilliQ $\mathrm{H}_{2} \mathrm{O}$

4. $10 \%$ Sucrose Gradient Buffer

Each sample uses $6 \mathrm{ml}$

$20 \mathrm{mM}$ Tris $\mathrm{pH} 8$

$15 \mathrm{mM} \mathrm{MgCl}_{2}$

$100 \mathrm{mM} \mathrm{NH}_{4} \mathrm{Cl}$

$2 \mathrm{mM}$ DTT

$10 \%$ sucrose

MilliQ $\mathrm{H}_{2} \mathrm{O}$

5. $50 \%$ Sucrose Gradient Buffer

Each sample uses $6 \mathrm{ml}$

$20 \mathrm{mM}$ Tris $\mathrm{pH} 8$

$15 \mathrm{mM} \mathrm{MgCl}_{2}$

$100 \mathrm{mM} \mathrm{NH}_{4} \mathrm{Cl}$

$2 \mathrm{mM}$ DTT

$50 \%$ sucrose

MilliQ $\mathrm{H}_{2} \mathrm{O}$

6. RNA Elution Buffer $(50 \mathrm{ml})$

$300 \mathrm{mM} \mathrm{NaOAc} \mathrm{pH} 5.5$

1 mM EDTA pH 8

MilliQ $\mathrm{H}_{2} \mathrm{O}$

7. DNA Elution Buffer $(50 \mathrm{ml})$

$300 \mathrm{mM} \mathrm{NaCl}$

$1 \mathrm{mM}$ EDTA pH 8

$10 \mathrm{mM}$ Tris $\mathrm{pH} 8$

MilliQ $\mathrm{H}_{2} \mathrm{O}$ 


\section{Acknowledgments}

Our work on ribosome profiling was supported by NIH grant GM110113. This protocol was adapted from the early bacterial profiling studies by Bukau and Weissman (Oh et al., 2011; Li et al., 2012; Becker et al., 2013) and incorporates recent improvements described by Ingolia for use in yeast and mammalian cells (McGlincy and Ingolia, 2017).

\section{Competing interests}

None

\section{References}

1. Baggett, N. E., Zhang, Y. and Gross, C. A. (2017). Global analysis of translation termination in E. coli. PLoS Genet 13(3): e1006676.

2. Balakrishnan, R., Oman, K., Shoji, S., Bundschuh, R. and Fredrick, K. (2014). The conserved GTPase LepA contributes mainly to translation initiation in Escherichia coli. Nucleic Acids Res 42(21): 13370-13383.

3. Becker, A. H., Oh, E., Weissman, J. S., Kramer, G. and Bukau, B. (2013). Selective ribosome profiling as a tool for studying the interaction of chaperones and targeting factors with nascent polypeptide chains and ribosomes. Nat Protoc 8(11): 2212-2239.

4. Burkhardt, D. H., Rouskin, S., Zhang, Y., Li, G. W., Weissman, J. S. and Gross, C. A. (2017). Operon mRNAs are organized into ORF-centric structures that predict translation efficiency. Elife 6: e22037.

5. Elgamal, S., Katz, A., Hersch, S. J., Newsom, D., White, P., Navarre, W. W. and Ibba, M. (2014). EF-P dependent pauses integrate proximal and distal signals during translation. PLoS Genet 10(8): e1004553.

6. Guo, M. S., Updegrove, T. B., Gogol, E. B., Shabalina, S. A., Gross, C. A. and Storz, G. (2014). MicL, a new sigmaE-dependent sRNA, combats envelope stress by repressing synthesis of Lpp, the major outer membrane lipoprotein. Genes Dev 28(14): 1620-1634.

7. Haft, R. J., Keating, D. H., Schwaegler, T., Schwalbach, M. S., Vinokur, J., Tremaine, M., Peters, J. M., Kotlajich, M. V., Pohlmann, E. L., Ong, I. M., Grass, J. A., Kiley, P. J. and Landick, R. (2014). Correcting direct effects of ethanol on translation and transcription machinery confers ethanol tolerance in bacteria. Proc Natl Acad Sci U S A 111(25): E2576-E2585.

8. Ingolia, N. T., Ghaemmaghami, S., Newman, J. R. and Weissman, J. S. (2009). Genome-wide analysis in vivo of translation with nucleotide resolution using ribosome profiling. Science 324(5924): 218-223. 
9. Kannan, K., Kanabar, P., Schryer, D., Florin, T., Oh, E., Bahroos, N., Tenson, T., Weissman, J. S. and Mankin, A. S. (2014). The general mode of translation inhibition by macrolide antibiotics. Proc Natl Acad Sci U S A 111(45): 15958-15963.

10. Lalanne, J. B., Taggart, J. C., Guo, M. S., Herzel, L., Schieler, A. and Li, G. W. (2018). Evolutionary convergence of pathway-specific enzyme expression stoichiometry. Cell 173(3): 749-761 e38.

11. Li, G. W., Burkhardt, D., Gross, C. and Weissman, J. S. (2014). Quantifying absolute protein synthesis rates reveals principles underlying allocation of cellular resources. Cell 157(3): 624-635.

12. Li, G. W., Oh, E. and Weissman, J. S. (2012). The anti-Shine-Dalgarno sequence drives translational pausing and codon choice in bacteria. Nature 484(7395): 538-541.

13. Liu, X., Jiang, H., Gu, Z. and Roberts, J. W. (2013). High-resolution view of bacteriophage lambda gene expression by ribosome profiling. Proc Natl Acad Sci U S A 110(29): 11928-11933.

14. Marks, J., Kannan, K., Roncase, E. J., Klepacki, D., Kefi, A., Orelle, C., Vazquez-Laslop, N. and Mankin, A. S. (2016). Context-specific inhibition of translation by ribosomal antibiotics targeting the peptidyl transferase center. Proc Natl Acad Sci U S A 113(43): 12150-12155.

15. McGlincy, N. J. and Ingolia, N. T. (2017). Transcriptome-wide measurement of translation by ribosome profiling. Methods 126: 112-129.

16. Meydan, S., Marks, J., Klepacki, D., Sharma, V., Baranov, P. V., Firth, A. E., Margus, T., Kefi, A., Vazquez-Laslop, N. and Mankin, A. S. (2019). Retapamulin-Assisted Ribosome Profiling Reveals the Alternative Bacterial Proteome. Mol Cell 74(3):481-493.

17. Mohammad, F., Green, R. and Buskirk, A. R. (2019). A systematically-revised ribosome profiling method for bacteria reveals pauses at single-codon resolution. Elife 8: 42591.

18. Oh, E., Becker, A. H., Sandikci, A., Huber, D., Chaba, R., Gloge, F., Nichols, R. J., Typas, A., Gross, C. A., Kramer, G., Weissman, J. S. and Bukau, B. (2011). Selective ribosome profiling reveals the cotranslational chaperone action of trigger factor in vivo. Cell 147(6): 1295-1308.

19. Shell, S. S., Wang, J., Lapierre, P., Mir, M., Chase, M. R., Pyle, M. M., Gawande, R., Ahmad, R., Sarracino, D. A., loerger, T. R., Fortune, S. M., Derbyshire, K. M., Wade, J. T. and Gray, T. A. (2015). Leaderless Transcripts and Small Proteins Are Common Features of the Mycobacterial Translational Landscape. PLoS Genet 11(11): e1005641.

20. Subramaniam, A. R., Deloughery, A., Bradshaw, N., Chen, Y., O'Shea, E., Losick, R. and Chai, Y. (2013). A serine sensor for multicellularity in a bacterium. Elife 2: e01501.

21. Weaver, J., Mohammad, F., Buskirk, A. R. and Storz, G. (2019). Identifying small proteins by ribosome profiling with stalled initiation complexes. MBio 10(2).

22. Woolstenhulme, C. J., Guydosh, N. R., Green, R. and Buskirk, A. R. (2015). High-precision analysis of translational pausing by ribosome profiling in bacteria lacking EFP. Cell Rep 11(1): 13-21. 
23. Zhang, Y., Burkhardt, D. H., Rouskin, S., Li, G. W., Weissman, J. S. and Gross, C. A. (2018). $\underline{A}$ stress response that monitors and regulates $m R N A$ structure is central to cold shock adaptation. Mol Cell 70(2): 274-286 e7. 